treatment (Fig. 11). With one inexplicable exception, the percentage of measurable antistaphylococcal serum titres in the cured dogs varied between 50 and 100 , as contrasted with 0 to $40 \%$ in the failures.

\section{Summary}

Clinical experience to date has shown that penicillinase resistant penicillins have earned a secure place in treatment of endocarditis caused by penicillinase producing staphylococci. Treatment should be continued for no less than four weeks. In an experimental model in dogs, data indicate that antistaphylococcal titres constantly maintained are more important in assuring successful eradioation of the staphylococcal infection than occasional high titres. Study of canine lesions also shows that valvular vegetations are sometimes easier to sterilize than infected suture lines.
Data on reported cases, provided through the courtesy of John E. Doyle, M.D., Bristol Laboratories, with the permission of Drs. W. M. M. Kirby, J. Stokes, III, A. C. White, S. Finegold, J. B. Wenzel, L. N. Brodsky, S. Katz, D. B. Louria, T. Sellers, Jr. P. J. Sweeny, A. Becker, and J. E. Geraci.

\section{REFERENCES}

Allen, J. D., Roberts, C. E., JR., KIrby, W. M. M (1962): New Engl. J. Med., 266, 111.

BunN, P. A., ed. (1960): Symposium on the new Dimethoxylphenyl Penicillins. State of New York Upstate Medical Center, Syracuse, N.Y. Campeau, LeONARD C., Lefebvre, M. (1961): Canad. med. Ass. J., 85, 491.

Douthwaite, A. H., Trafford, J. A. P., McGill, D. A. F., Evans, I. E. (1961): Brit. med. J. ii, 6 . DOYLE, J. E. (1964): Personal Communication.

QuinN, E. L. (1964): Personal Communication.

Sabath, L. D., Postic, B., Finland, M. (1962): New Engl. J. Med., 267, 1049.

Simon, H. J., RANTZ, L. A. (1962): Ann. intern. Med., 57, 335.

Walker, W. F., Hamburger, M. (1959): J. lab. Clin. Med. 53, 931.

\title{
TREATMENT OF BACTERIAL ENDOCARDITIS WITH ORAL PENICILLINS
}

I. R. GRAY,

Consultant Physician and Cardiologist Coventry Group of Hospitals.

A. R. TAI, Medical Registrar, Gulson Hospital, Coventry.

BEFORE the advent of antibiotics, bacterial endocarditis was almost invariably fatal. The introduction of penicillin altered the prognosis but problems in treatment are still encountered as the organisms are deeply embedded in the heart valves and vegetations. The early and prolonged use of penicillin can now produce a cure in most cases but severe damage to the valves may occur leading to progressive heart failure.

The commonest infecting organism is Streptococcus viridans. In 29 consecutive cases we have seen in whom positive blood cultures were obtained this organism was grown in 20 $(69 \%)$. This organism is usually highly sensitive to penicillin, the minimum inhibitory concentration (or M.I.C.) being $0.03 \mu \mathrm{g} . / \mathrm{ml}$. or less. At the present time the usual treatment of such infections is intramuscular penicillin $\mathbf{G}$.
J. G. Wallace,

Deputy Director, Public Health Laboratory, Coventry.

J. H. Calder,

Medical Adviser, Beecham Research Laboratories.

in a dosage of at least 2 megaunits daily.

Streptococcus facalis is another frequent organism-it is usually less sensitive to penicillin than Strept. viridans, the M.I.C.s of different strains varying between 1.25 and 12.5 $\mu \mathrm{g} . / \mathrm{ml}$. Penicillin and steptomycin are often synergistic in their action on this organism and this antibiotic combination has been successfully used. The introduction of $\alpha$ amino-benzyl penicillin or ampicillin provided a new approach to the treatment of Strept. faccalis infections as this antibiotic is usually about twice as active against the organism as penicillin G.

Two patients presented with bacterial endocarditis in whom the causative organism was a Strept. faccalis more sensitive to ampicillin than to penicillin $G$ or any other antibiotic. Ampicillin controlled the infection in both 
TABLE I

Details of 13 Patients with Bacterial Endocarditis Treated with Penicillin by Mouth.

\begin{tabular}{|c|c|c|c|c|c|c|c|}
\hline No. Name & $\begin{array}{l}\text { Age } \\
\text { and } \\
\text { sex }\end{array}$ & Lesions & Blood Culture & $\begin{array}{l}\text { M.I.C. in } \\
\text { Serum } \\
(\mu \mathrm{g} . / \mathrm{ml} .)\end{array}$ & $\begin{array}{c}\text { Peak Serum } \\
\text { level } \\
(\mu \mathrm{g} . / \mathrm{ml} .)\end{array}$ & Treatment & Course \\
\hline 1. D.O. & $59 \mathrm{~F}$ & A.R. & Str. fæcalis & & & $\begin{array}{l}\text { Ampicillin } 2 \text { g., } \\
\text { Erythromycin } \\
2 \text { g., daily }\end{array}$ & Recovery \\
\hline 2. A.G. & $41 \mathrm{~F}$ & M.S., A.R. & Str. fæcalis & 4.00 & & $\begin{array}{l}\text { Ampicillin } 2.5 \mathrm{~g} \text {. } \\
\text { then } 5.0 \mathrm{~g} \text {., }\end{array}$ & $\begin{array}{l}\text { Relapse then } \\
\text { recovery, died } \\
\text { congestive failu }\end{array}$ \\
\hline 3. J.B. & $26 \mathrm{M}$ & $\begin{array}{l}\text { V.S.D., } \\
\text { P.S. }\end{array}$ & Str. viridans & 1.00 & & $\begin{array}{l}\text { daily } \\
\text { Propicillin } \\
1.25 \text { g., daily }\end{array}$ & $\begin{array}{l}\text { congestive failu } \\
\text { Recovery }\end{array}$ \\
\hline 4. J.W. & $22 \mathrm{M}$ & Fallot & Str. viridans & 0.50 & & Propicillin & Recovery \\
\hline 5. J.H. & $48 \mathrm{M}$ & A. $R$. & Sterile & & & $\begin{array}{l}\text { Propicillin } \\
1.25 \text { g., daily }\end{array}$ & Recovery \\
\hline 6. O.M. & $47 \mathrm{~F}$ & A.R, M.R. & Str. viridans & 0.12 & & $\begin{array}{l}\text { Propicillin } \\
2.5 \text { g., daily }\end{array}$ & $\begin{array}{l}\text { Died. Ruptured } \\
\text { aortic valve }\end{array}$ \\
\hline 7. E.S. & $68 \mathrm{M}$ & A.S. & Str. viridans & 0.50 & 11.00 & $\begin{array}{l}\text { Propicillin } \\
2.5 \text { g., daily }\end{array}$ & Recovery \\
\hline 8. M.L. & $26 \mathrm{~F}$ & M.S. & $\begin{array}{l}\text { Str. viridans } \\
\text { Str. pneumoniæ }\end{array}$ & & 18.00 & $\begin{array}{l}\text { Ampicillin } \\
1.0-2.0 \mathrm{~g} . \\
\text { daily }\end{array}$ & $\begin{array}{l}\text { Penicillin } \\
\text { sensitivity } \\
\text { Recovery }\end{array}$ \\
\hline 9. B.B. & $24 \mathrm{M}$ & A. $\mathbf{R}$. & Str. viridans & 0.25 & 18.00 & $\begin{array}{l}\text { Propicillin } \\
2.5 \text { g., } \\
\text { Probenecid } 2 \mathrm{~g} . \text {, } \\
\text { daily }\end{array}$ & $\begin{array}{l}\text { Infection cured } \\
\text { Coronary } \\
\text { embolism. Died } \\
\text { cardiac failure }\end{array}$ \\
\hline 10. V.C. & $29 \mathrm{~F}$ & M.R. & Str. viridans & 0.50 & 17.50 & $\begin{array}{l}\text { Probenecid } 2 \mathrm{~g} . \text { } \\
\text { Propicillin } 2 \mathrm{~g} \text {. } \\
\text { daily. }\end{array}$ & Recovery \\
\hline 11. J.C. & $58 \mathrm{M}$ & A.S. & Sterile & & 6.10 & $\begin{array}{l}\text { Propicillin } 2.5 \mathrm{~g} . \\
\text { Probenecid } 2 \mathrm{~g} . \\
\text { daily }\end{array}$ & Recovery \\
\hline 12. E.J. & $49 \mathrm{~F}$ & M.R. & Str. viridans & 0.50 & 17.50 & $\begin{array}{l}\text { Propicillin } 2 \text { g. } \\
\text { Probenecid } 2 \text { g., } \\
\text { daily }\end{array}$ & $\begin{array}{l}\text { Recovery } \\
\text { Penicillin } \\
\text { sensitivity }\end{array}$ \\
\hline 13. A.M. & $29 \mathrm{~F}$ & A.R., M.R. & Str. viridans & 1.00 & 29.30 & $\begin{array}{l}\text { Propicillin } 2.5 \mathrm{~g} \text {. } \\
\text { Probenecid } 2 \mathrm{~g} . \\
\text { daily }\end{array}$ & Recovery \\
\hline
\end{tabular}

patients although in one it recurred two months later necessitating a second course of ampicillin together with streptomycin. Success in these two cases led us to consider oral therapy in bacterial endocarditis generally, as prolonged treatment with intramuscular penicillin is always an ordeal for the patient. It was decided to use propicillin for patients with Strept. viridans infection since significantly higher serum levels had been reported than with other phenoxypenicillins.

Thirteen patients with bacterial endocarditis have been treated with oral penicillin-the two patients already mentioned together with a further eleven consecutive cases (Table I). Blood culture was positive in 11 of the 13 . Strept. viridans was isolated in 8 patients, Strept. focalis in 2 and both Strept. viridans and Strept. pneumonioe in 1 case.

Propicillin was given to ten patients and ampicillin to three. The antibiotic was given four-hourly usually omitting one dose during the night. The usual dose was $500 \mathrm{mg}$. foure hourly, although one or two of the early cases were given $250 \mathrm{mg}$. four-hourly and occasion? ally $1 \mathrm{~g}$. four-hourly was used. Probeneciơ was given to five patients in order to inhibit the excretion of penicillin and raise the serum and tissue levels. The dosage was $0.5 \mathrm{~g}$. six-hourly? Treatment was given for six-weeks except ing Case 8 where it was stopped a little sooner ore account of hypersensitivity.

Infection was controlled in all patients. There was recurrence in Case 2 after two months buf a second course was apparently effective. Nळ0 patient died during treatment but two diec within three months from cardiac failure and third died during attempted surgical repair of perforated aortic valve.

Levels of propicillin in the serum weres 

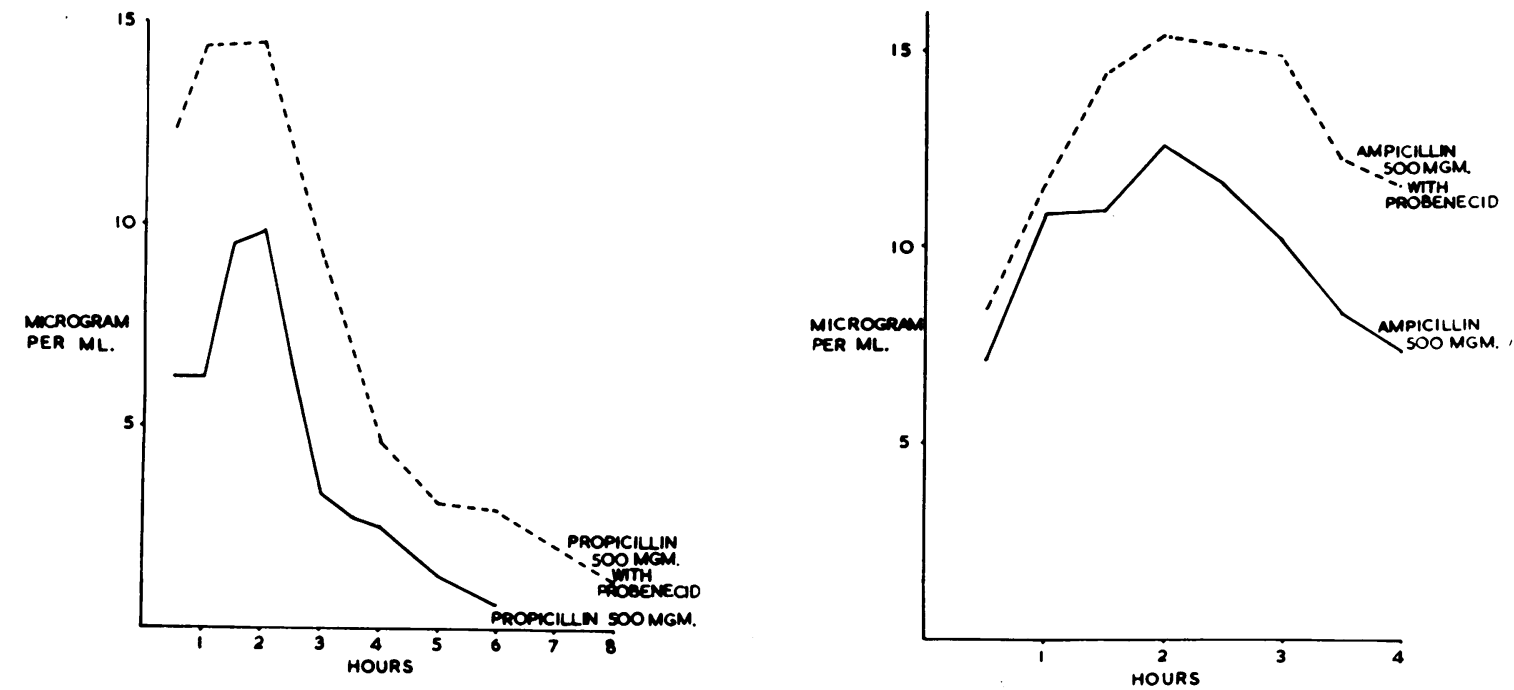

FIG. 1.-Blood levels of propicillin and ampicillin with and without probenecid.

estimated in six patients and one patient having ampicillin was also studied. With propicillin, peak levels in the blood were reached after $1 \frac{1}{2}-2$ hours (Fig. 1). When pwobenecid was given as well propicillin levels were approximately $50 \%$ higher. In the patient having ampicillin the peak levels occurred two hours after the latest dose but the increase with probenecid was about $25 \%$ (Fig. 1). Quite a wide variation in peak serum concentrations was found in different patients-peak concentrations after $500 \mathrm{mg}$. propicillin with probenecid varied from 6.1 to $32.5 \mu \mathrm{g}$. $/ \mathrm{ml}$. Repeated estimations in the same patient showed a lesser variation.

Caution must be taken in interpreting the serum levels of different penicillins. McCarthy and Finland (1960) pointed out that the "antibacterial activity" of different penicillins did not correspond with that expected from considering the serum concentration of the penicillin and the M.I.C. as obtained with broth cultures. It was shown by Bond et. al. (1963) that this discrepancy seemed to correspond with the binding of a fraction of the penicillin to serum protein. They also showed a corresponding decrease in the sensitivity to penicillins when organisms were tested in the presence of serum as compared with broth. Their results indicate that only the free penicillin and not the total penicillin should be considered in judging the adequacy of serum levels or that, alternatively, total blood levels should be compared with inhibitory concentrations estimated in the presence of serum.
Nine of the cultures obtained from our patients were tested against propicillin and against ampicillin in broth and also in humap serum (Table II). The M.I.C.s of propicillim were about eight times as high in serum as in broth culture suggesting that between 80 and. $90 \%$ of the propicillin was rendered inactive it serum. With ampicillin the difference was insignificant.

We have chosen to compare the total serum levels of antibiotic with the M.I.C. estimated in serum. On this basis the peak serum levels were more than 20 times the M.I.C. in all five patients where full data were available. It seems likely however that in Case 2 where the Strept. facalis was not very sensitive even to ampicillin that the serum levels were not sufficiently high to eradicate the infection and this might explain the relapse.

Any of the phenoxy-penicillins is likely to be effective against nearly any strain of Strept. viridans. Although we used propicillin and found it perfectly satisfactory, the high degree of protein-binding means that its high serum concentration does not indicate a correspondingly high anti-bacterial activity.

Penicillin V and phenethicillin produce a higher serum anti-bacterial activity for a given dose than the others of this group.

Ampicillin is as effective against Strept. viridans as the phenoxypenicillins and is not sig- $\theta$ nificantly inactivated by serum protein. A greater margin between serum anti-bacterial : activity and M.I.C. is therefore to be expected. 
TABLE II

M.I.C.s of Propicillin and Ampicillin for Organisms Isolated from nine patients.

\begin{tabular}{cccccc}
\hline & & \multicolumn{3}{c}{ Minimum Inhibitory Concentration in $\mu \mathrm{g}$. $/ \mathrm{ml}$. } \\
Patient & Organism & Broth & Serum & Broth & Serum \\
A.G. & Str. fæcalis & 8.00 & 32.00 & 2.00 & 4.00 \\
J.S. & Str. viridans & 0.12 & 1.00 & 0.03 & 0.03 \\
J.W. & Str. viridans & 0.06 & 0.50 & 0.03 & 0.03 \\
O.M. & Str. viridans & 0.03 & 0.12 & 0.015 & 0.03 \\
E.S. & Str. viridans & 0.03 & 0.50 & 0.03 & 0.12 \\
B.B. & Str. viridans & 0.03 & 0.25 & 0.06 & 0.12 \\
V.C. & Str. viridans & 0.06 & 0.50 & 0.12 & 0.25 \\
E.J. & Str. viridans & 0.06 & 0.50 & 0.12 & 0.12 \\
A.M. & Str. viridans & 0.25 & 1.00 & 0.03 & 0.03 \\
\hline
\end{tabular}

Furthermore ampicillin is likely to be much more effective than any of the phenoxypenicillins in infections with Strept. faecalis. These arguments seem to favour ampicillin as the oral penicillin of choice when the diagnosis of bacterial endocarditis is suspected but the result of blood culture is not yet available.

\section{Conclusion}

We have treated 13 patients with bacterial endocarditis with oral penicillins, ten with propicillin and three with ampicillin. Infection was controlled in every case but relapse occurred once.

We found a dosage of $500 \mathrm{mg}$. four-hourly ( 2.5 g. per day) satisfactory and found that probenecid 0.5 g. six-hourly increased the serum levels considerably.

Between 80 and $90 \%$ of the propicillin in serum appeared to be inactivated and we there- fore compared serum levels with M.I.C.sor estimated in the presence of human serum. Even so the peak serum levels were more than20 times the M.I.C. in all cases where full data were available.

Although only three of our patients we actually treated with ampicillin, the broad andibacterial spectrum of this antibiotic and the absence of inactivation by serum protein suggesto that it is preferable to any of the phenox penicillins for the oral treatment of bacterialo endocarditis before the results of blood culture and antibiotic sensitivity tests are available. If the organism is found to be highly sensitive, one of the phenoxypenicillins can be substituted.

\section{REFERENCES}

Bond, J.M., Lightbown, J. W., BARber, M., WATERWORTH, P. M. (1963): Brit. med. J., ii, 956. McCarthy, C. G., Finland, M. (1960): New Engl. J. Med., 263, 215. 